\title{
THE EVOLUTION OF STATE AID POLICY IN POLAND IN THE LIGHT OF EXPERIENCE OF EU MEMBER STATES
}

\section{General Remarks}

The problem of aid awarded to enterprises from public funds has aroused controversy in Poland for a long time. The growing interest in these issues was caused by the accession negotiations and then by Poland's entry into the European Union. The rules of awarding and monitoring the state aid turned out to be one of the most crucial areas of negotiation. Support for private enterprises from state funds is controversial because beneficiaries of such aid are always in a privileged position in relation to the other entities operating on a given market. For that reason, such an interference in the market mechanism has to be well-thought out and planned each time, and carried out only when it is justified by some important economic or social interest. This issue appears to be more essential as the practice of various forms of state intervention in economy of Poland is extremely widespread, which, on the one hand, is a legacy of the previous economic system, while on the other it is the reaction to the adverse social effects of transformation processes. Consequently, it is of utmost importance to plan and conduct the policy of State aid appropriately, and especially to determine the optimal amount, purpose and forms of this aid, and the efficacy of utilization of the awarded financial support. ${ }^{1}$ After Poland's accession to the European Union, these problems must be considered in the context of the need to harmonize the Polish provisions concerning the procedures of awarding and monitoring State aid with the EU standards. ${ }^{2}$

1 See P. Jasiński, Priorytety polityki pomocy publicznej w Polsce (in:) Priorytety pomocy publicznej w Polsce, (eds.). P. Jasiński, E. Kaliszuk, E. Modzelewska - Wąchal, A. Lubbe, Polskie Forum Strategii Lizbońskiej, Gdańsk 2003.

See inter alia: E. Czerwińska, Pomoc publiczna dla przedsiębiorców a konieczność dostosowania prawa polskiego do prawa Unii Europejskiej, Information No. 713. Biuro Studiów i Ekspertyz, Warsaw 2000. A. Kamieński, pomoc publiczna dla przedsiębiorców - aspekty prawne, "Glosa" No. 11/2004. A. Werner, Polskie postępowanie notyfikacyjne dotyczące udzielenia pomocy publicznej, "Glosa” 10/2004. R. Zajdler, Procedury udzielania pomocy publicznej, "Prawo Unii Europejskiej” No. 7-8/2004. I. Postuła, A. Werner, Pomoc publiczna, Wyd. LexisNexis, Warsaw 2006. 
On account of the origin of term 'State aid's as well as the source of regulations that underlie it, the natural reference to the description of State aid policy in Poland is the experience of the other EU Member States in this field. ${ }^{4}$ They are the basis for the assessment of the current practice of awarding State aid in Poland, including first of all its level, structure and the degree of implementation of the adopted objectives.

\section{Determinants of State Aid in the System of Community Law and their Evolution}

The Treaty Establishing the European Community (hereinafter the TEEC) showed the conditions that must be met so that a given financial support can be regarded as State aid. In particular, four main criteria are distinguished: ${ }^{5}$

1. aid has to be granted by a Member State or from public funds regardless of the form,

2. the result of aid is the distortion of competition manifested in the obtainment of economic advantages that cannot be obtained without such support,

3. aid has a selective character, therefore it applies only to selected regions, sectors, industries or enterprise,

4. aid influences trade between Member States.

At the same time, under the TEEC, aid measures that meet the aforementioned criteria were found to be incompatible with the common market rules. The rule of incompatibility, however, is not identical with a total prohibition because exceptions (derogations) to this general rule have been introduced, both automatic and conditional as long as the adverse results of State aid might be compensated for by their positive consequences. ${ }^{6}$

The group of automatic exemptions includes aid for the following purposes: socially targeted at individual consumers (on condition it is granted without restriction as to the origin of goods), intended to compensate for damage due to natural disasters,

3 What the European Community calls State aid is termed 'public aid' in Polish. This aid has not been directly defined in the Community law, but only by showing some prerequisites that allow us to assess whether or not a given form of State intervention constitutes aid. Various definitions of the term can be found in numerous publications on the subject, e.g.: S. Dudzik, Pomoc państwa dla przedsiębiorstw publicznych w prawie Wspólnoty Europejskiej: między neutralnością a zaangażowaniem, Kantor Wydawniczy "Zakamycze", Krakow 2002. P. Pełka, M. Stasiak, Pomoc publiczna dla przedsiębiorców w Unii Europejskiej i w Polsce, Difin, Warsaw 2002. E. Modzelewska - Wąchal, Pomoc publiczna dla przedsiębiorców i jej nadzorowanie, LexisNexis, Warsaw 2003.

$4 \quad$ P. Jasiński, Priorytety polityki..., op. cit., p. 11.

5 Art. 87 section 1 of the Treaty Establishing the European Community (consolidated text - EU Official Journal of 24 December 2002. C 235), henceforward TEEC

$6 \quad$ Art. 87 (2) Art. 87 (3), TEEC 
and awarded to Germany's regions especially affected by the division of Germany ${ }^{7}$. The goal of State intervention in these cases is to prevent adverse social-economic effects or restore the state that existed prior to the occurrence of circumstances (natural disasters or any other extraordinary events) that brought about these adverse phenomena. $^{8}$

Conditional exemptions, however, apply, inter alia, to: aid awarded to support economic development in especially backward regions or those hit by high unemployment, i.e. regional intervention. This group also includes aid for the implementation of projects of all-European importance or for the elimination of serious disruptions to the economy of the Member States. Additionally, the aid is also admitted to facilitate the development of certain forms of activities, including small and medium-sized enterprises. Conditional exemptions also apply to aid targeted at the promotion of culture and preservation of cultural heritage.

The foregoing exemptions show that Community law distinguishes three principal purposes of State aid: horizontal, sectoral and regional objectives. ${ }^{9}$

Horizontal aid does not depend on where beneficiaries conduct business activity or which sector they belong to. It may be targeted at all entrepreneurs, who, owing to State support, will implement strictly defined goals, which include rescuing and restructuring ${ }^{10}$, the support for small and medium-sized enterprises, research and development, training, and environmental protection..

A characteristic feature of sectoral aid is that it is targeted under an assistance program at a specific group of entrepreneurs to whom the State wants to grant aid because they belong to a particular sector. It most often applies to the so-called 'sensitive sectors', which are characterized by surplus production capacity and capital-intensive investments. Difficulties that occur in these sectors constitute justifiable grounds for granting aid but with a reservation that this must not lead to a serious distortion of competition and a privileged position of its beneficiaries in relation to the other entrepreneurs. These sectors include, above all, the automotive sector, steel and coal sectors, textile sector, and shipbuilding.

The regions entitled to obtain regional aid are those with the GDP per capita level lower by at least $25 \%$ than the overall Community average ${ }^{11}$, and additionally, in the regions where the unemployment rate exceeds the EU average by $10 \%$, this difference has been increased to $15 \%$. Furthermore, the aid can also be awarded

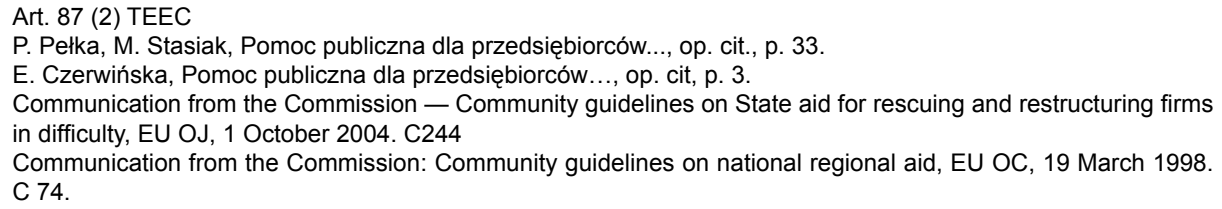


to the so-called problem areas defined on the basis of national indicators proposed by Member States. Three kinds of aid are available here: aid for initial investment, aid for the creation of jobs, or operational aid earmarked for covering current costs of the functioning of enterprises operating in the regions with particularly severe socio-economic problems. The European Commission's guidelines on regional aid indicate that it should focus on the economically most underdeveloped regions in the EU while the national policies of regional aid should be consistent with the objectives implemented on the level of the whole Community within the framework of structural funds.

At the same time, the European Commission has special powers to decide whether a given aid measure qualifies to be excluded, while each Member State is obligated to notify the Commission about the planned forms and kinds of aid measures prior to the commencement of their implementation (the so-called ex ante notification). Nor can the State implement aid measures until they have been approved by the Commission (the so-called principle of suspension). All assistance granted without the Commission's consent is automatically deemed illegal and has to be returned. In order to simplify procedures pertaining to the notification of State aid, the Commission recently adopted five regulations exempting certain categories of aid from the duty of prior notification. These apply to the aid to small and medium sized enterprises ${ }^{12}$, the aid for employment ${ }^{13}$, the training aid ${ }^{14}$, the regional investment aid $^{15}$, and de minimis aid. ${ }^{16}$

As regards the forms of State aid preferred in the European Union, i.e. the manner of transferring public funds to entrepreneurs, Community law permits two kinds of intervention: direct and indirect ones. In the former case, the aid consists in direct reallocation of funds from the public finance sector to the beneficiary, e.g. granting credit or loan on more favorable terms than on the market, or granting a subvention. This kind of aid is active and pro-development and it is directly implemented through the system of public expenditure whereas we can speak of indirect aid in the case of

12 A small enterprise is one that employs fewer than 50 employees, its annual turnover not exceeding 10 million euros, while a medium-sized one - under 250 employees with a turnover below 50 million euro. Commission Regulation no. 70/2001 of 12 January 2001 on the application of Articles 87 and 88 of the EC Treaty to State aid to small and medium-sized enterprises OJ. L 10 of 13.01 .2001$.

13 Commission Regulation No. 2204/2002 of 5 December 2002 on application of Articles 87 and 88 of the EC Treaty to State aid for employment. OJ L 337 of 13.12.2002.

14 Commission Regulation No. 68/2001 of 12 January 2001 on the application of Articles 87 and 88 of the EC Treaty to training aid, OJ L10 of 13.01.2001.

15 Commission Regulation No. 1628/2006 of 24 October 2001 on the application of Articles 87 and 88 of the EC Treaty to national regional investment aid, OJ L 302 of 1.11.2006 .

16 The de minimis aid is a gain granted to the entrepreneur over three consecutive years up to the amount of 200 thousand euros (in the road transport sector - up to 100 thousand euro). This rule applies regardless of the enterprise size, consequently, it is especially beneficial to small and medium-sized businesses, moreover, granting de minimis aid is not conditional upon the classification of it into one of the aforementioned exceptions to the general prohibition of State aid. Commission Regulation No. 1998/2006 of 15 December 2006 on the application of Articles 87 and 88 of the EC Treaty to de minimis aid. OC L 379 of 28.12. 2006. 
omission to collect (despite the fact that there is a legal obligation to do so) specific public funds and leaving them in the entrepreneur's possession, e.g. remission of tax arrears or tax deferrals. This aid tends to be termed as 'forced aid' because it is passive and consists in the reduction of due budgetary receipts due.

A certain specification of the aforementioned guidelines of the Community law on the policy of State aid in the EU territory are the conclusions contained in the Lisbon Strategy adopted in $2000^{17}$ as well as the conclusions and suggestions formulated by the European Commission at the half point of the Strategy implementation in 2005. ${ }^{18}$ They emphasized the need to reduce the GDP share of State aid gradually in individual Member States and the need to redirect this aid especially for horizontal objectives, including cohesion. At the same time it was accentuated that what should be reduced first of all is the aid that has a particularly distortive effect on competition and the aid whose efficacy is the lowest, which was expressed as a maxim 'less aid but a better targeted aid.' Consequently, State aid in EU countries should focus first of all on such areas as: developing economy based on knowledge that takes into account the development of information society, promotion of research and innovation processes, education and training, development of small and medium-sized enterprises, and the environmental protection. Another priority directed this aid towards the creation of conditions conducive to the development of entrepreneurship, inter alia stimulation of high-risk capital investment. An important objective of assistance can also be a better targeting of regional support for sustained development and modernization as well as improvement of the European social model. The Commission also specified its stance on so-called public services, which play a crucial role in the provision of social and territorial cohesion. A very important issue was also the improvement in the efficacy of aid granted and the wider application of ex ante and ex post assessments to aid schemes from the perspective of verifying the effectiveness of support and its effect on competition. The emphasis was also laid on the need to amend transparency rules of awarding aid and to improve monitoring and reporting in this field.

17 The Lisbon Strategy adopted in March 2000 is the socio-economic program of the European Union whose aim is to make the EU the world's leading economy in the perspective of 2010. For more on this document see the Internet, e.g. , www.pfsl.pl for Poland.

18 Communication from the Commission to the Council and the European Parliament, Common Actions for Growth and Employment: The Community Lisbon Program, COM (2005) 330 final, SEC (2005) 981. Brussels 20.07.2005. 


\section{Comparative Presentation of State Aid granted in EU Countries and in Poland}

The comparative analysis of the empirical data contained in the European Commission's annual reports on State aid awarded in the EU Member States and in the Office of Competition and Consumer protection reports on State aid in Poland allows us to formulate several general conclusions ${ }^{19}$.

Firstly, the average amount of State aid in the Community is gradually reduced both in absolute values and relative to GDP (see Tables 1 and 2). ${ }^{20}$ What is also characteristic is that the downward trend continued even after the accession of ten new states to the Community in 2004. However, there are considerable disparities between EU Member States regarding the amount of funds earmarked for support: the share of aid to GDP (apart from agriculture, fisheries and transport) in 2006 ranged from $0.13 \%$ in Luxemburg to $1.77 \%$ in Malta (Table 2). In Poland, in turn, the level of aid in 1998-2003 clearly increased, which was connected with both the need for such a support resulting from the economic crisis and a growing imbalance of the public finance sector, and with the wish to take advantage of the last opportunities in this field before the accession to the Community. ${ }^{21}$

Table 1. Amount of State aid and as percentage of GDP in EU and in Poland in 1998-2006*)

\begin{tabular}{|l|c|c|c|c|c|c|c|c|c||}
\hline Specification & 1998 & 1999 & 2000 & 2001 & 2002 & 2003 & 2004 & 2005 & 2006 \\
\hline State aid in Poland in PLN billion & 6.8 & 9.1 & 7.7 & 11.28 & 10.3 & $\left.28.6^{*}\right)$ & 16.4 & 4.8 & 5.9 \\
\hline State aid in Poland as \% of GDP & 1.15 & 1.40 & 1.06 & 1.47 & 1.31 & 3.50 & 1.90 & 0.50 & 0.60 \\
\hline $\begin{array}{l}\text { State aid excluding transport in } \\
\text { Poland in PLN billion }\end{array}$ & N/A & N/A & N/A & N/A & N/A & N/A & 8.8 & 3.6 & 4.5 \\
\hline $\begin{array}{l}\text { State aid excluding transport in } \\
\text { Poland as \% of GDP }\end{array}$ & N/A & N/A & N/A & N/A & N/A & N/A & 1.00 & 0.40 & 0.43 \\
\hline $\begin{array}{l}\text { average State aid in EU -15 } \\
\text { excluding agriculture, fisheries and } \\
\text { transport in EURO billion }\end{array}$ & 50.2 & 40.3 & 42.6 & 45.9 & 50.6 & 41.6 & 43.7 & 44.2 & 44.7 \\
\hline
\end{tabular}

19 See Report State Aid Scoreboard-Autumn 2007 Update-Brussels, 13.12.2007 COM(2007) 791 final and Raport o pomocy publicznej w Polsce udzielonej przedsiębiorcom w 2003 r., UOKiK [OCCP], Warsaw, November 2004 and Raport o pomocy publicznej udzielonej przedsiębiorcom w 2006. Warsaw, October 2007. [Raport on State aid in Poland awarded to entrepreneurs in 2003., and Report on State aid in Poland awarded to entrepreneurs in 2006 ].

20 Figures for State aid in Poland and EU are not fully comparable because before 2004 there were significant methodological disparities in reporting, manifested in that the European Commission reports do not take into account the funds earmarked for, inter alia, transport, including railways, which constituted a sizable volume of State aid in Poland.

21 B. Woźniak, Zasady funkcjonowania i zakres publicznego systemu finansowego (in:) System finansowy w Polsce, (ed.). B. Pietrzak, Z. Polański, B. Woźniak, PWN 2004. 
Katarzyna Wójtowicz

\begin{tabular}{|c|c|c|c|c|c|c|c|c|c|}
\hline $\begin{array}{l}\text { average State aid in EU }-15 \\
\text { excluding agriculture, fisheries and } \\
\text { transport as } \% \text { of GDP }\end{array}$ & 0.55 & 0.43 & 0.43 & 0.46 & 0.50 & 0.41 & 0.42 & 0.42 & 0.41 \\
\hline $\begin{array}{l}\text { average State aid in EU }-25 \\
\text { excluding agriculture, fisheries and } \\
\text { railway transport in EURO billion }\end{array}$ & - & - & - & - & - & - & 47.5 & 47.3 & 47.9 \\
\hline $\begin{array}{l}\text { average State aid in EU }-25 \\
\text { excluding agriculture, fisheries and } \\
\text { transport as \% of GDP }\end{array}$ & - & - & - & - & - & - & 0.44 & 0.43 & 0.42 \\
\hline
\end{tabular}

*) Figures for Poland in the Table are not fully comparable because in 1999-2000 State aid awarded in agriculture was not taken into account, while starting from 2004 State aid is taken into account excluding transport, in accordance with EU methodology

${ }^{* *}$ On account of the fact that 2003 was the year preceding Poland's entry into the EU, endeavors were made to take the "last chance" to award a considerable, one-time subsidy to the coal sector before this aid would be subject to evaluation by the European Commission, for conformity with the Community law.

Source: Report State Aid Scoreboard-Autumn 2007 Update-Brussels, 13.12.2007 COM(2007) 791 final and Raport o pomocy publicznej w Polsce udzielonej przedsiębiorcom w 2003 r., UOKiK, Warsaw November 2004 and Raport o pomocy publicznej udzielonej przedsiębiorcom $w 2006$ r., Warsaw October 2007. [see footnote 19 for translation)

From 2004 on one can observe a positive phenomenon consisting in the systematic reduction of the amount of aid, which is consistent with the recommendations set forth in the Lisbon Strategy. In 2006 the percentage of State aid (excluding transport) in GDP $(0.43 \%)$ basically corresponded to the average for the whole EU-25 $(0.42 \%)$ and it was considerably lower than the average for the ten new Member States $(0.52 \%)$.

Table 2. Amount of State aid and its share in GDP in EU Member States in 2006

\begin{tabular}{|l|c|c|c|c|}
\hline Country & $\begin{array}{c}\text { State aid } \\
\text { excluding railway } \\
\text { transport } \\
\text { in EURO billion }\end{array}$ & $\begin{array}{c}\text { State aid } \\
\text { excluding railway } \\
\text { transport } \\
\text { as \% of GDP }\end{array}$ & $\begin{array}{c}\text { State aid } \\
\text { excluding } \\
\text { agriculture, } \\
\text { fisheries and } \\
\text { railway transport } \\
\text { in EURO billion }\end{array}$ & $\begin{array}{c}\text { State aid } \\
\text { excluding } \\
\text { agriculture, } \\
\text { fisheries and } \\
\text { railway transport } \\
\text { as \% of GDP }\end{array}$ \\
\hline EU -25 & 66.7 & 0.58 & 47.9 & 0.42 \\
\hline EU-15 & 61.1 & 0.56 & 44.7 & 0.41 \\
\hline EU-10 & 56 & 0.91 & 3.2 & 0.52 \\
\hline Belgium & 1.2 & 0.39 & 0.9 & 0.28 \\
\hline Czech Republic & 0.8 & 0.66 & 0.6 & 0.51 \\
\hline Denmark & 1.3 & 0.59 & 1.0 & 0.46 \\
\hline Germany & 20.2 & 0.87 & 16.0 & 0.69 \\
\hline
\end{tabular}


The Evolution of State Aid Policy in Poland in the Light of Experience...

\begin{tabular}{|l|l|l|l|l|}
\hline Estonia & 0.1 & 0.41 & 0.0 & 0.08 \\
\hline Ireland & 1.0 & 0.57 & 0.5 & 0.28 \\
\hline Greece & 0.6 & 0.26 & 0.3 & 0.15 \\
\hline Spain & 4.9 & 0.50 & 3.9 & 0.39 \\
\hline France & 10.4 & 0.58 & 7.4 & 0.41 \\
\hline Italy & 5.5 & 0.37 & 3.8 & 0.26 \\
\hline Cyprus & 0.1 & 0.76 & 0.1 & 0.48 \\
\hline Latvia & 0.3 & 1.80 & 0.0 & 0.15 \\
\hline Lithuania & 0.1 & 0.54 & 0.1 & 0.23 \\
\hline Luxemburg & 0.1 & 0.32 & 0.0 & 0.13 \\
\hline Hungary & 1.4 & 1.57 & 0.8 & 0.93 \\
\hline Malta & 0.1 & 2.29 & 0.1 & 1.77 \\
\hline Netherlands & 1.9 & 0.35 & 1.3 & 0.24 \\
\hline Austria & 2.3 & 0.90 & 1.6 & 0.60 \\
\hline Poland & 2.3 & 0.85 & 1.2 & 0.43 \\
\hline Portugal & 1.5 & 0.93 & 1.4 & 0.91 \\
\hline Slovenia & 0.3 & 0.83 & 0.1 & 0.48 \\
\hline Slovakia & 0.2 & 0.51 & 0.2 & 0.45 \\
\hline Finland & 2.6 & 1.53 & 0.6 & 0.35 \\
\hline Sweden & 1.15 & 2.9 & 0.94 \\
\hline United Kingdom & 0.22 & 3.1 & 0.16 \\
\hline & & & & 0.1 \\
\hline
\end{tabular}

Source: Report State Aid Scoreboard -Autumn 2007 Update-Brussels, 13.12.2007 COM(2007) 791 final

Secondly, the analysis of the structure of overall State aid objectives in the European Union (Table 3) shows that the greatest percentage goes to horizontal aid, accounting for almost $85 \%$ of total aid volume in EU-25 countries and to circa $78 \%$ of EU-10 members, while horizontal aid also comprises regional aid accounting for $19 \%$ of total aid granted in the whole Community. The share of sectoral aid in EU amounted to $15 \%$ in 2006 (in EU-10 - 22\%). 
Katarzyna Wójtowicz

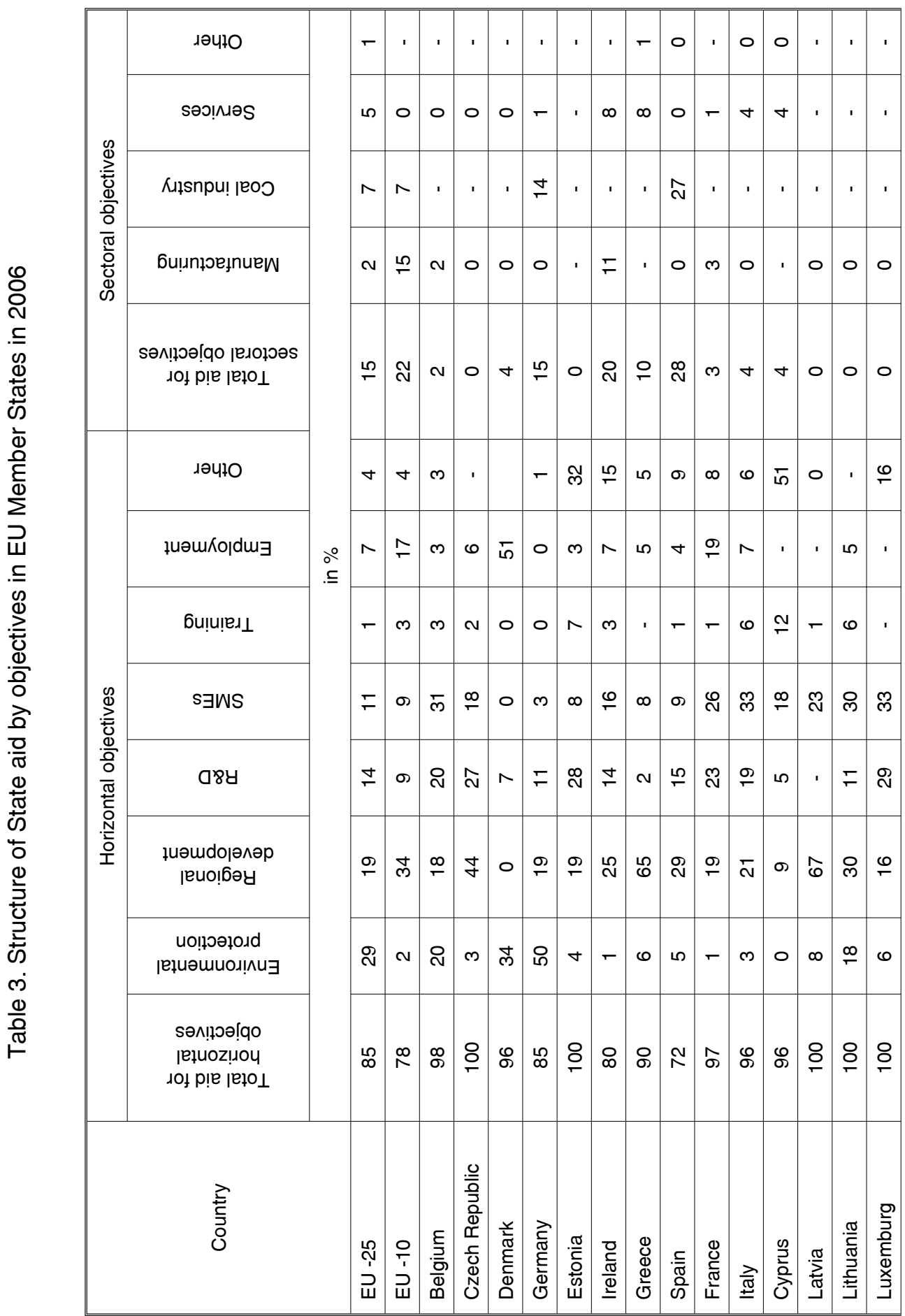


The Evolution of State Aid Policy in Poland in the Light of Experience...



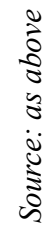


In Poland horizontal aid also dominates in the structure of State aid, amounting to almost 50\% in 2005-2006 (see Table 4). It should be noted that by the end of 2003 these proportions were entirely different and almost $70 \%$ of the aid was earmarked for sector objectives (first of all for the coal industry). At present, in most EU countries, horizontal aid is directed mainly (apart from environmental protection objectives) for research and development and for small and medium-sized enterprises. Like in the other EU-10 countries, the support for employment and regional aid is of great importance in Poland. In the structure of sector aid, a comparatively great role is still played by the aid earmarked for the coal industry. Unfortunately, in the light of the data on the deteriorating condition of this economic sector in Poland, and of many press articles pointing to the pathologies attendant on this form of aid, the efficacy and efficiency of this kind of support can be regarded as extremely dubious.

Table 4. State aid by objectives in Poland in 2003 and in 2005-2006

\begin{tabular}{|c|c|c|c|c|c|c|}
\hline \multirow[b]{2}{*}{ Aid objectives } & \multicolumn{2}{|c|}{2003} & \multicolumn{2}{|c|}{2005} & \multicolumn{2}{|c|}{2006} \\
\hline & $\begin{array}{c}\text { Amount of } \\
\text { aid in PLN } \\
\mathrm{m} .\end{array}$ & Share as $\%$ & $\begin{array}{l}\text { Amount of } \\
\text { aid PLN m. }\end{array}$ & Share as $\%$ & $\begin{array}{c}\text { Amount of } \\
\text { aid in PLN } \\
\mathrm{m} .\end{array}$ & Share as \% \\
\hline TOTAL & 28627.5 & 100.0 & 3646.2 & 100 & 4468.4 & 100 \\
\hline Horizontal aid: & 2840.8 & 9.9 & 1821.7 & 49.9 & 2183.1 & 48.9 \\
\hline$R \& D$ & 105.6 & 3.7 & 153.1 & 8.4 & 127.6 & 5.8 \\
\hline environmental protection & 346.0 & 12.2 & 31.3 & 1.7 & 55.5 & 2.5 \\
\hline $\begin{array}{l}\text { small and medium-sized } \\
\text { enterprises }\end{array}$ & 146.6 & 4.7 & 304.5 & 16.7 & 322.6 & 14.8 \\
\hline employment & 296.1 & 10.4 & 1230.3 & 67.6 & 1440.0 & 66.0 \\
\hline training & 66.0 & 2.3 & 89.3 & 4.9 & 210.1 & 9.6 \\
\hline aid for rescue & 1750.3 & 61.6 & 4.6 & 0.3 & 11.3 & 0.5 \\
\hline aid for restructuring & 144.9 & 5.1 & 8.5 & 0.5 & 16.0 & 0.7 \\
\hline Sectoral aid: & 20214.9 & 70.6 & 1048.5 & 28.8 & 699.8 & 15.7 \\
\hline shipbuilding sector & 456.7 & 2.3 & 184.7 & 17.6 & 103.6 & 14.8 \\
\hline coal sector & 17488.5 & 86.5 & 863.8 & 82.4 & 596.2 & 85.2 \\
\hline Regional aid & 863.7 & 3.0 & 763.6 & 21.0 & 1558.3 & 34.9 \\
\hline OTHER & 32754.4 & 16.5 & 12.4 & 0.3 & 27.2 & 0.5 \\
\hline
\end{tabular}

Source: Raport o pomocy publicznej udzielonej przedsiębiorcom w 2006 r., Warsaw October 2007 (Compare figures for 2003 from Report on State aid in Poland awarded to entrepreneurs in 2003, UOKiK, Warsaw November 2004). 
The Evolution of State Aid Policy in Poland in the Light of Experience...

The figures in Table 5 show that in 2004-2006 both in Poland and in the EU the dominant ones were direct forms of support, first of all as grants whose share stood at circa $50 \%$. This phenomenon should be positively assessed because the grant is the most transparent instrument of aid. Compared to, in 1997-2004, indirect forms of aid were of key importance in the structure of State aid in Poland (Table 6). It should be noted that this situation was characteristic of most acceding States and was the effect of the weak condition of the enterprise sector, especially of large State-owned companies that had problems with discharging their public obligations, and from the weak condition of public budgets plagued by deficits, in which it was difficult to find funds to cover directs grants.

Table 5. Forms of State aid in EU and in Poland in 2004-2006

\begin{tabular}{|c|c|c|c|c|c|c|}
\hline \multirow{2}{*}{ Specification } & \multicolumn{6}{|c|}{ Share of each aid type in total aid as \% } \\
\cline { 2 - 7 } & grants & $\begin{array}{c}\text { tax } \\
\text { subsidies }\end{array}$ & $\begin{array}{c}\text { capital- } \\
\text { investment } \\
\text { subsidies }\end{array}$ & soft loans & $\begin{array}{c}\text { payment } \\
\text { deferrals }\end{array}$ & guarantees \\
\hline EU-25 & 50 & 43 & 1 & 3 & 2 & 2 \\
\hline Poland & 52 & 41 & 0 & 3 & 0 & 4 \\
\hline
\end{tabular}

*) Share calculated on the basis of the average amount of aid granted in the manufacturing and services sectors in 2004-2006

Source: as above

Table 6. The Structure of State aid in Poland by support forms

\begin{tabular}{|l|c|c|c|c|c|c|c|c|c|c|c|}
\hline \multirow{2}{*}{ Specification } & 1997 & 1998 & 1999 & 2000 & 2001 & 2002 & 2003 & 2004 & 2005 & 2006 \\
\cline { 2 - 10 } & \multicolumn{8}{|c|}{ in \% } \\
\hline $\begin{array}{l}\text { Direct support } \\
\text { forms }\end{array}$ & 31.3 & 34.5 & 34.9 & 47.3 & 25.8 & 38.0 & 9.7 & 37.7 & 77.1 & 78.5 \\
\hline $\begin{array}{l}\text { Indirect support } \\
\text { forms }\end{array}$ & 68.7 & 65.5 & 65.1 & 52.7 & 74.2 & 62.0 & 90.3 & 62.3 & 22.9 & 21.5 \\
\hline
\end{tabular}

Source: Raport o pomocy publicznej udzielonej przedsiębiorcom w 2006 r., Warszawa October 2007 


\section{Final Conclusions}

While assessing the evolution of State aid policy in Poland, we should first of all emphasize that after its accession to the Community, Poland has been faced with considerable problems in adjusting its policy to EU standards.

Firstly, the amount of State aid granted shows a clear downward turn, and in 2006 it was even reduced to the level corresponding to the average for the whole EU (relative to GDP). This is in line with the Community recommendations but it should be taken into account that under the specific Polish conditions we should not accept Community guidelines uncritically and follow the wealthier countries of the "old" European Union, which are better adapted to compete on the common market. A decrease in the amount of aid awarded should be a long-term goal, which should, however, be attained gradually, taking into account the repercussions it may have for Polish economy, especially for the domestic entrepreneurs, who need support during the process of restructuring and making up for technological delays.

Secondly, it was possible to redirect the awarded aid from sector objectives towards horizontal and regional ones. Consequently, most funds have recently been earmarked towards projects for employment, small and medium-sized enterprises, as well as for R\&D, and investment support. This tendency should be positively assessed because it will contribute to the improvement of competitiveness of Polish firms, especially the sector of small and medium-sized enterprises, which constitute the majority of economic entities in Poland and play a significant role in the process of economic development and job creation. We should have in mind, however, that in the EU Member States these changes were introduced successively as the objectives of aid were achieved, while the present low share of aid for 'sensitive sectors' is a consequence of earlier restructuring and modernization activities, which Poland has not yet completed. For that reason, it is also desirable in Poland that the aid should be redirected successively rather than by fits and starts so that the adopted objectives will contribute to the satisfactory improvement of the economy in Poland and bridging of the development gap between Poland and EU countries. ${ }^{22}$

Thirdly, the forms of aid awarded were also changed. Tax concessions, exemptions, and remissions of public law obligations that were overwhelmingly applied until recently, have been replaced by direct budget expenditures in the form of grants. This is the most convenient and most effective form of aid. Although it has to be used in accordance with its purpose, it allows beneficiaries a certain flexibility of action and enables them to increase the capital investment greatly. On the other hand, from the standpoint of public authorities, the reduction of aid in the form of various tax exemptions is highly desirable because it enables the acquisition of 
funds necessary for financing aid for the enterprises that appear promising enough to use this aid effectively and eventually improve their economic performance (which may also contribute in the long run to an increase in public budget revenue from taxes they will pay).

To sum it up, we should stress once again that while adjusting the state policy in Poland to the rules and practices of the EU countries, we should not disregard its specific determinants in Poland, which are: firstly - the scarcity of public funds earmarked for aid (which results in strong competition between various objectives and beneficiaries), and secondly, - a great number of social and economic needs that require state intervention (those result from high unemployment rate, the structural weakness of the small and medium-size enterprise sector, or incomplete restructuring processes). ${ }^{23}$ The foregoing conditions unequivocally show that the principal indicator of aid granted from public funds should be its efficacy and efficiency. In particular, it is necessary to develop a long-term strategy that would take European Commission recommendations into account and embrace these processes on the national scale, first of all in the context of the impact of granted aid on the expenditure of the public finance sector. 


\section{Streszczenie}

Artykuł jest próbą oceny rozwoju polityki pomocy publicznej w Polsce po akcesji do Unii Europejskiej. W szczególności prezentuje prawne determinanty tej pomocy począwszy od klauzul zawartych w Traktacie ustanawiającym Wspólnotę Europejska i regulacjach Komisji Europejskiej. Obejmuje także charakterystykę porównawczą pomocy publicznej przyznanej w krajach UE i w Polsce pod względem wielkości wsparcia, jej przedmiotu - pomoc horyzontalna, regionalna i sektorowa, czy też ze względu na jej formy - bezpośrednią i pośrednią. Główny wniosek płynący z rozważań stanowi, że po akcesji do UE, Polska szeroko przystosowała politykę pomocy publicznej do standardów prawa unijnego i do praktyki innych państw członkowskich.

Oceniając postęp Polski w tej dziedzinie, nie powinno się lekceważyć specyficznych czynników, do których należą: po pierwsze - niedobór środków publicznych przeznaczonych na wsparcie, co skutkuje silnym współzawodnictwem pomiędzy różnymi podmiotami i beneficjentami; po drugie - wielki zakres potrzeb o charakterze socjalnym i ekonomicznym, które wymagają finansowania ze strony państwa i które skutkują wysoką skalą bezrobocia, osłabieniem strukturalnym sektora małych i średnich przedsiębiorstw lub niekompletnym procesem restrukturyzacji. 